\section{Revista de Literatura, História e Memória

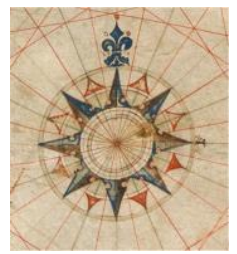

Seção: Pesquisa em Letras no contexto Latino-americano e Literatura, Ensino e Cultura

ISSN 1983-1498

VOL. 17 - No 30 - 2021

U N I O E S T E / CA S C A V E L - p. 255-269

\title{
HISTÓRIA E FICÇÃO EM CARTA À RAINHA LOUCA, DE MARIA VALÉRIA REZENDE
}

\author{
History and fiction in Carta à rainha louca, by Maria \\ Valéria Rezende
}

André Luís Gomes de Jesus ${ }^{1}$

RESUMO: No presente artigo analisamos Carta à rainha louca (2019), de Maria Valéria Rezende a relação entre discurso histórico e discurso ficcional que se manifesta a partir da voz da protagonista. Para tanto, nos utilizamos da noção de imagemrelâmpago (BENJAMIN, 2012) e de sua reformulação realizada por Didi-Huberman (2015). Rezende constitui um trabalho narrativo em que História e ficção se entrecruzam de modo a fazer emergir a figura de Isabel, mulher inserida no contexto das relações sociais da Brasil-Colônia, sofrendo sanções e opressões destinadas a quem ocupava as margens do poder político e econômico, bem como formas de driblar e resistir a tais sanções (FEDERICI, 2019).

PALAVRAS-CHAVE: Ficção e História; Literatura feminina; Maria Valéria Rezende; voz excêntrica.

ABSTRACT: In this article we aim at analyzing Carta à rainha louca (2019), by Maria Valéria Rezende the connexion between historical discourse and fictional discourse manifests themselves in the protagonist's voice. In order to do so, we used the notion of lightning image (BENJAMIN, 2012) and its reformulation carried out by Didi-Huberman (2015). Rezende creates a narrative work in which History and fiction overlap in order to bring out the figure of Isabel, a woman inserted in the context of social relations in Colonial Brazil, suffering sanctions and oppressions aimed at those who occupied the margins of the political and economic power, as well as ways to circumvent and resist such sanctions (FEDERICI, 2019).

KEYWORDS: Fiction and History; Female Literature; Maria Valeria Rezende; Ex-centric voice

\section{INTRODUÇÃO}

Um dos desafios de quem se propõe a analisar o conjunto da produção romanesca brasileira contemporânea é a de captar, entre as inúmeras linhas de força que convivem e concorrem no interior dessa produção, aspectos de renovação escritural e/ou temática que apontem para novas inflexões no conjunto da criação literária no Brasil.

É possível reconhecer, no âmbito de nossa literatura, uma radicalização escritural que, em última instância, aponta para o esvaziamento do regime de autonomia da obra literária, proposta pelo Modernismo na esteira das Vanguardas do início do século XX. Tal

\footnotetext{
${ }^{1}$ Doutor em Letras (Teoria Literária) pela Universidade Estadual Paulista, campus São José do Rio Preto com estágio doutoral pela Université Nouvelle Sourbonne - Paris 5. Mestre em Letras (Literaturas em Lingua Portuguesa) pelo Instituto de Biociências, Letras e Ciências Exatas - UNESP de São José do Rio Preto/SP.
} 
esvaziamento aponta para um texto que se insinua como literário, mas que, em certa medida, quebra com alguns pactos inerentes à ficção, constituindo-se como objetos que fundem realidade e ficção, personalismo e alteridade, referencialidade e ficcionalidade (LUDMER, $2007)^{2}$, desnudando a porosidade entre a esfera literária, pensada ao longo do projeto vanguardista como fundante de uma realidade própria, e a chamada realidade empírica, constituída per si como um recorte representacional do homem em sua relação com a linguagem. É importante mencionar que, apesar de certo modo esvaziar o projeto modernista, tais objetos escriturais se inserem, paradoxalmente, num conjunto de produção artística que parecem herdeiros dos procedimentos advindos das Vanguardas ${ }^{3}$.

Se, por um lado, temos um conjunto de textos tidos como literários que indicam uma espécie de esvaziamento da própria noção de autonomia que caracterizou o ser-da-literatura, por outro, podemos encontrar um conjunto de narrativas que podem ser pensadas como continuidade - mas não de mesmice - de um modo de realização literária que se insere em formas tradicionais de narração e que se utilizam da linearidade, da sucessão temporal, da memória, do testemunho como seus elementos fundantes.

Essas narrativas incorporam as renovações escriturais propostas ao longo de nossa produção literária e lhe dão uma nova inflexão, permitindo que aspectos estéticos esboçados no modo acurado de escrita convivam com uma temática que, em última instância, aponta para a representação de grupos historicamente marginalizados que assumem um lugar de protagonismo, permitindo-lhes relativizar as narrativas oficiais que caracterizaram nossa formação identitária, cultural e histórica. São, desse modo, narrativas que antecipam um modo de existência multipolar em que as vozes ex-cêntricas ${ }^{4}$ ganham relevo e assumem a possibilidade de se dizer e de dizer o seu lugar no mundo. É possível afirmar, nesse sentido, que os produtores de tais textos estão mais interessados nos desdobramentos éticos de sua escrita, do impacto que elas causam a partir da perspectiva dos temas que são impulsionados,

\footnotetext{
2 Josefina Ludmer propõe em seu manifesto Literaturas pós-autônomas uma mudança na própria noção de literatura, chamando a atenção para, pelo menos dois grandes blocos de criação literária: a dos romances históricos, ainda presentes no contexto de produção literária da Argentina (e, também da América Latina como um todo), e textos que a princípio não estariam englobados como literários porque relativizam a ideia de autonomia do artefato literário. Além de Ludmer, Florencia Garramuño (2014) e Reinaldo Laddaga (2012; 2013) também apontam para uma reformulação do regime das artes nesse início de século.

${ }^{3}$ No Brasil, podemos afirmar que escritores como Jacques Fux e Ricardo Lísias apontam, em seus textos, para esse esvaziamento da produção literária autônoma. Esses escritores fazem isso a partir do embaralhamento entre as esferas ficcional e real, assumindo suas escritas como elementos em que pessoalidade e alteridade convivem de um modo que esses aspectos não se anulem. Para melhor compreensão dessas questões Cf. ALVES (2019); SOUZA (2020).

${ }^{4}$ A noção de ex-cêntricidade diz respeito à presença de vozes que ocupam as margens do centro de poder em artefatos culturais contemporâneos (chamados por alguns críticos de Pós-Modernos). Cf. Poetica do PosModernismo, de Linda Hutcheon.
} 
o que não implica afirmar um descuido com os processos estéticos da produção narrativa.

Podemos usar como exemplos dessa literatura que pode ser classificada como politicamente engajada romances como Desmundo (1996), de Ana Miranda; Dois irmãos (2000), de Miltom Hatoum; Um defeito de cor (2006), de Ana Maria Gonçalves; Torto arado (2019), de Itamar Vieira Junior; Carta à rainha louca (2019), de Maria Valéria Rezende, etc. Esses romances, produzidos ao longo dos últimos trinta anos, embora pareçam manter um olhar de continuidade no que diz respeito a um projeto escritural tradicional, assumem um caráter fundamentalmente arrojado quando o assunto são as temáticas que deles emergem. São textos em que personagens silenciadas pela História oficial podem, ao menos da perspectiva ficcional, afirmar sua alteridade enquanto elemento de resistência.

Esse é o caso de Carta à rainha louca, romance da escritora paulista e radicada na Paraíba, Maria Valéria Rezende. O romance, escrito em quatro partes - na verdade uma longa carta dividida em quatro períodos temporais que representam interrupções da escrita ao longo de quatro anos - 1789 a 1792, configura-se como um relato pessoal da protagonista Isabel das Santas Virgens à D. Maria I, rainha de Portugal. O objetivo do relato da protagonista é o de se defender da acusação de herética, embora saiba de antemão que essa defesa surtirá pouco ou nenhum efeito, dada a sua condição de mulher. Para a composição do romance, Rezende se vale de um acurado trabalho de pesquisa ${ }^{5}$ que tem como resultado uma espécie de restauração da Língua Portuguesa falada no século XVIII em terras brasileiras. Ao longo do presente texto, analisamos Carta à rainha louca, a partir de ao menos dois eixos fundamentais: a) a relação dialética com a História de modo a constituir uma representação de uma voz marginal - a da mulher; b) a relação discursiva estabelecida entre Isabel das Virgens e sua interlocutora, a rainha, de modo a descortinar as violências sofridas pelas mulheres durante o processo colonial. Para tanto, utilizamos críticos como Benjamin (2012), Didi-Huberman (2015) e Federici (2019), entre outros.

\footnotetext{
${ }^{5}$ Acerca da produção de Maria Valéria Rezende, é possível afirmar que existe um trabalho de pesquisa literária que resulta numa diversidade de representações e formas de afirmar essas representações. Se tomamos como exemplos romances como $O$ voo da guará vermelha (2005), Quarenta dias (2014) e Carta à rainha louca (2019), observamos algumas permanências que podemos afirmar estilísticas e éticas - a opção pela representação de figuras não pertencentes ao centro de poder econômico ou simbólico - e, também, algumas rupturas, a exemplo de uma passagem de narradores oniscientes para narradores-protagonistas. Nos últimos dois romances lidamos com narradoras-protagonistas femininas que retomam o seu vivido e contam suas dificuldades a partir de uma escrita que também se configura como um desafio - no caso de Alice, protagonista de Quarenta dias, a dificuldade de organizar os escritos em papeis achados pelas ruas enquanto estava perdida por Porto Alegre num velho caderno, já Isabel a dificuldade de ter papel e tinta numa colônia carente de tudo. Podemos afirmar que Alice e Isabel são facetas do mesmo feminino marginalizado no país.
} 


\section{A RELAÇÃO ENTRE HISTÓRIA E LITERATURA NA CONSTRUÇÃO DA NARRATIVA}

Um dos aspectos fundamentais da literatura contemporânea brasileira é a da constituição de inventários críticos à ideia estereotipada do que sejam identidade, cultura e história brasileiras. É preciso ver nessa produção uma perspectiva de combate aos discursos que tratam o ser-brasileiro como uma concepção homogênea e unívoca, sem fissuras e constituída a partir de processos que, apesar de marcados pela violência em seus mais variados aspectos, são ideologicamente pacificados na constituição da ideia de grande nação. Carta à rainha louca se insere nesse campo de produção, uma vez que trata, a partir de um ponto de vista do contradiscurso das versões oficiais do processo histórico brasileiro. Isso se dá a partir da trajetória de Isabel das Virgens, uma mulher branca que, contudo, ocupa um lugar marginal por não pertencer aos estratos sociais abastados, desnudando as estruturas do poder colonial em sua lógica de agregação e de marginalização de acordo com o poder econômico, bem como dos interesses político-sociais.

Em Dialética da colonização (1992), Alfredo Bosi chama a atenção para o modo como o pensamento colonial se organiza, sobretudo, no regime de plantation que se estabelece em territórios utilizados para a exploração e o enriquecimento da Metrópole por meio do pacto colonial. Para o crítico, o pensamento colonial se esboça num processo dialético em que a dominação da terra para o cultivo de produtos considerados economicamente fundamentais para a burguesia mercantil metropolitana - a colonização exploratória - se encontra, de certo modo, com outras maneiras de dominação colonial - a colonização cultural esboçada, sobretudo, na transposição e aclimatação dos valores culturais metropolitanos para o ambiente colonial: valores familiares, religião, instituições estatais que, uma vez aclimatadas, assumem uma dimensão mais radical no mundo colonial.

No romance de Maria Valéria Rezende, essa relação é revelada desde o incipit, uma vez que é a partir da relação de diferença entre Isabel, Blandina ou D. Maria I que se mostra as semelhanças de tratamento recebido pelas mulheres, independentemente de seu estrato social:

Senhora,

Perdoai, Vossa Majestade Fidelíssima, a esta mulher - enlouquecida pelas penas do amor ingrato e de grandes vilanias cometidas por aqueles que se creem mais poderosos do que Vós mesma - por vir-Vos interromper, com o relato de seus sofrimentos de mínimo relevo, em Vossas orações e em Vossos atos régios tão urgente para Vosso Reino e para aquele de Deus. 
Por louca e desobediente encarceraram-me neste Recolhimento da Conceição, no alto das colinas desta cidade de Olinda, famosa por sua beleza e pelo fausto ostentado em outras eras, quando branco e doce era o ouro destas terras [...] Há longo tempo me trouxeram para cá, com o fim de aguardar alguma nau de carreira que me levasse à Lisboa, para ser julgada pelas Cortes por um crime que me foi assacado, mas aqui me esqueceram (REZENDE, 2019, p. 09 - grifos nossos).

O início do relato de Isabel descortina ao menos algumas questões fundamentais: a) a protagonista, presa no Recolhimento, uma espécie de prisão para as mulheres, situa-se discursivamente como mulher enlouquecida e desobediente, ou seja, num primeiro momento parece aderir ao julgamento que o mundo dos homens faz de sua pessoa, impondo-se um lugar marginal diante de sua interlocutora - a rainha; b) é interessante ainda pensar que a protagonista também se situa do ponto de vista histórico, uma vez que a narrativa se passa nos últimos anos do século XVIII, quando o eixo de poder político havia sido transferido para o Rio de Janeiro e que a região das Minas Gerais, já em decadência, era centro de minerador da Colônia. Todas essas informações da narradora são importantes porque é exatamente no contraponto dessa dominação que as personagens femininas se colocam, desde a sua origem: "Por vezes já não sei ao certo se nasci e fui criada no Engenho Paraíso, um dos maiores e mais ricos daquele recôncavo que cerca da cidade de São Salvador da Bahia. [...] porém, vejo em minha mente todos os recantos daquela casa, onde me senti muitas vezes infeliz" (REZENDE, 2019, p. 55).

O relato de Isabel é organizado de um modo em que angústia e desorientação são dominantes. É como se a protagonista se valesse da escrita para não só se reorganizar, mas também constituir uma defesa do seu papel marginal. O relato torna-se mais linear na terceira parte, denominada "1791, quando Isabel conta o encontro entre ela, Blandina e Diogo Lourenço que, depois de seduzir a filha de senhor de engenho, parte, deixando-a grávida. O pai de Blandina usando de seu poderio econômico e, também, simbólico - um homem num mundo de homens - envia a filha para o claustro em Salvador e permite que Isabel, uma mulher deserdada e sem o pai presente a acompanhe ao Convento. O próprio processo de reclusão de ambas as personagens demonstra, no âmbito do texto, que as mulheres ocupavam no território colonial, um lugar de subalternidade que independia de sua origem ou condição financeira.

É importante pensarmos no romance de Maria Valéria Rezende como um documento que aponta tanto para o passado quanto para o presente das relações da mulher com a sociedade na qual está inserida. Isto porque, a despeito das mudanças ocorridas e dos direitos 
adquiridos, o papel da mulher segue diminuído e subalterno em nossa realidade. De certo modo, a autora se vale de uma personagem feminina inserida num contexto histórico distante, primeiro para pontuar a resistência dessa mulher, bem como descortinar toda uma cadeia de autoritarismo e perversão que permanece intocada. Em outras palavras: a opressão do presente é tributária das opressões do passado.

Rezende, estudiosa da História da América Latina, situa a origem de seu romance numa especialização realizada no México em meados dos anos 1980. Ali, a escritora entra em contato com uma série de relatos de opressão autoritária às mulheres e, também, com as formas utilizadas por elas para resistirem a tais opressões ${ }^{6}$. Após alguns estudos, a escritora vai a Portugal e pesquisa na Torre do Tombo alguns documentos referentes a processos da Inquisição contra mulheres consideradas heréticas e desobedientes e se depara com a carta de uma mulher que, obrigada, segundo ela mesma diz, a escrever para se defender, afirma saber de antemão o resultado negativo de sua defesa a partir da sua consciência de ser mulher. Temos, então, nesse dado de História a origem da narrativa ficcional escrita trinta anos depois ${ }^{7}$.

Podemos afirmar, desse modo, que o embricamento entre História e ficção na narrativa em questão é realizada a partir da noção de imagem histórica que obriga o leitor a observar os acontecimentos históricos a contrapelo. Essa noção de História a contrapelo tem sua origem no texto de Walter Benjamin em que trata das teses sobre a História (BENJAMIN, 2012). No texto, Benjamin chama a atenção para a metodologia da Ciência Histórica que lê os acontecimentos a partir do ponto de vista dos vencedores. Aos vencidos, de acordo com esta perspectiva, só resto o esquecimento. No entanto, para o filósofo, mais que uma História que também contemple a imagem dos vencidos, é preciso uma narrativa que trate o processo histórico em sua complexidade e, para isso, Benjamin se vale da ideia de imagem-relâmpago que recupera um acontecimento, fazendo com que, a partir desse encontro entre a ocorrência e o pensador, haja uma reformulação da História. Teríamos nessa metodologia um contradicurso das narrativas oficiais e ela estaria esboçada na constituição de constelações históricas que, em última instância, estabelecem relações dialógicas com outros acontecimentos históricos, bem como, com o presente. É nesse sentido que, para Benjamin, a imagem-relâmpago serve

\footnotetext{
${ }^{6}$ Em palestra proferida em maio de 2019, por ocasião do lançamento do livro em Campina Grande, Maria Valéria Rezende cita a especialização no México como uma fonte importante para a composição do romance, graças ao contato com a História de personagens femininas que conseguiram, senão contornar plenamente, resistir às perseguições. Dois exemplos citados são de Sóror Juana Inéz de la Cruz e Rosa Maria Egipcíaca, esta última perseguida pela Inquisição portuguesa.

${ }^{7}$ Estas são afirmações de Rezende a uma reportagem realizada no Correio braziliense para a jornalista Nahima Maciel em 15/04/2019.
} 
como forma de redenção do passado: "na ideia que fazemos da felicidade vibra também inevitavelmente a da redenção. O mesmo se passa com a ideia de passado de que a história se apropriou" (BENJAMIN, 2012, p.10).

Essa noção de História, retomada por Didi-Huberman em Diante do tempo (2015), é pensada pelo filósofo e historiador da arte a partir da concepção de imagem-malícia. DidiHuberman vê a História como um longo encadeamento de imagens-mônadas que se relacionam de modo alinear e instantâneo. É nesse processo dialógico que a imagem do passado "brilha" no presente e reassume a sua importância, pois é capaz de redefinir e dar um novo significado aos acontecimentos, sem, no entanto, anular as versões antigas. Desse modo, para Didi-Huberman:

a história se fundamenta e recomeça -, segundo Benjamin, em um movimento "a contrapelo" da antiga busca do passado pelo historiador. É preciso compreender, a partir de então, em quê o passado vem ao historiador e, de certa maneira, como o encontra no seu presente, entendido então como presente reminiscente (DIDI-HUBERMAN, 2019,p. 115 - grifos do autor).

$\mathrm{O}$ encontro entre o presente reminiscente e a imagem do passado estabelecem uma relação de não-linearidade que acabam por constituir a ideia de imagem-malícia que nada mais é do que esse feliz encontro entre um fato do passado e alguém capaz de estabelecer com esse fato uma relação redentora.

Quando levamos em consideração as afirmações de Maria Valéria Rezende acerca da construção de seu romance, percebemos que felizes circunstâncias levaram a autora a encontrar a carta de uma senhora que na região da Minas mantinha uma casa em que mulheres brancas e sem condições econômicas ou sociais para o casamento podiam se abrigar. Pelo gesto de constituição dessa comunidade feminina, essa mulher é acusada pela Coroa e pela autoridade religiosa de manter uma espécie de convento clandestino numa região em que eles não podiam existir. Na carta original, a acusada assume, segundo Rezende em sua entrevista para o Correio Braziliense, uma posição de autodefesa irônica, uma vez que ela mesma considera esse gesto inútil. É interessante notar que o encontro da carta por Rezende funciona como a ideia da imagem-relâmpago de Benjamim e que somente depois de trinta anos a autora, já consagrada como romancista, retoma o fato não mais para tratá-lo como fato histórico, mas sim como uma espécie de gérmen para a sua experiência ficcional. Em outras palavras, a autora (re)cria o universo dessa mulher de modo a, senão propor uma redenção, constituir um inventário da vida da mulher colonial.

É interessante ainda notar que, em vez de assumir uma perspectiva de cronista 
histórica, Maria Valéria vai se valer do discurso criativo inerente à ficção para, de modo inventivo, recriar o contexto em que a autodefesa da mulher acusada pela Inquisição se dá, dando a ela uma história e um nome. Essa posição nos leva a pensar nas reflexões que Jacques Rancière faz acerca da própria constituição da História enquanto disciplina científica. Em $O s$ nomes da História (2014), Rancière chama a atenção para uma virada essencial da História a partir de sua adesão a representações histórica das multidões e dos espaços. No entanto, para o filósofo, à medida que adere e incorpora a multidão na sua discursividade, a História silencia a sua voz, opondo-se ao que Rancière chama de excesso de palavras. Rezende, a partir da consciência dos limites do discurso histórico, escolhe a criação ficcional exatamente porque ela the permite a constituição de discurso em que verossimilhança e possibilidade emergem como dados fundamentais.

Como dissemos acima, é possível refletir acerca da narrativa de Rezende não só como retomada de um dado histórico, mas também como (re)atualização e atestado de que pouquíssimas coisas mudaram, de fato, na vida das mulheres ao longo de quase trezentos anos. É preciso, contudo, não perder de vista que a relação com a História não tem por objetivo propor uma nova versão de fatos históricos vividos no Brasil do setecentos. Tampouco há, da parte da protagonista, quaisquer relações com personagens reais, sendo D. Maria $\mathrm{I}^{8}$ mais uma construção discursiva que é mobilizada para o estabelecimento de uma interlocução que é sempre adiada: "Quanta aflição passei por tantos meses, Senhora, se poder retomar da pena para cumprir o que Vos havia prometido: dizer toda a verdade sobre o que em Vosso nome se faz nestas terras e a mim me fizeram” (REZENDE, 2019, p. 39).

Nesse sentido, podemos dizer que, do ponto de vista da construção narrativa, Carta à rainha louca não estabelece uma relação de revisão de acontecimentos históricos, mas de inserção de uma voz contrapontística que descortina a realidade das figuras ex-cêntricas no âmbito da sociedade colonial. Na próxima sessão demonstraremos as formas de resistência assumidas pela protagonista.

\section{O GESTO E A PALAVRA: EXISTÊNCIA E RESISTÊNCIA}

Como vimos na sessão anterior, Carta à rainha louca estabelece uma relação dialógica entre História e Ficção para, por meio da (re)criação de uma possível vivência no contexto do

\footnotetext{
${ }^{8}$ A escolha de D. Maria I como interlocutora se deve também ao fato de a rainha de Portugal ter sido a primeira mulher reinante daquele país, tendo, inclusive, vivido um processo de silenciamento e alienação de seu poder depois da morte do rei corsorte D Pedro III em 1785. D. Maria, vítima de uma depressão profunda, foi declarada mentalmente incapaz em 1792 e seu filho D. João de Bragança assumiu o poder como Regente até sua morte em 1816.
} 
setecentos, revelar os múltiplos modos de exclusão das figuras não pertencentes ao centro de poder no período. Além disso, é possível ainda constituir paralelismos entre o contexto do setecentos e o mundo contemporâneo, sobretudo, no que diz respeito ao direito das mulheres. O romance não só demonstra as múltiplas violações à liberdade individual - vale lembrar que, exatamente nesse período já circulava na Colônia os valores advindos da Iluminismo -, mas também constitui Isabel das Santas Virgens como uma personagem que representa a resistência dessas figuras marginais. É preciso compreender, desse modo, que a construção caracteriológica proposta por Rezende para sua personagem tem como molde a carta irônica dirigida aos representantes do poder metropolitano (Coroa, Inquisição, etc.), mas desdobra essa defesa numa trajetória marcada pelo desejo de sobrevivência. Podemos afirmar, então, que Isabel resiste tanto nas ações que marcam sua existência quanto nas reflexões que propõe acerca delas quando escreve sua carta-defesa à rainha.

A trajetória de Isabel é marcada pela perda constante. Nascida em território brasileiro e filha de camponeses portugueses, a protagonista perde a mãe muito cedo e acaba por crescer entre os escravizados do engenho em que o pai vive como uma espécie de jagunço-agregado. É na adolescência que a vida de Isabel muda, quando se vê sozinha no mundo devido à fuga de seu pai pelo assassinato do feitor do engenho que tenta violar Isabel.

A partir desse ponto temos a inserção da protagonista como moradora agregada da casa-grande e dama de companhia de Blandina, a filha mais velha do proprietário das terras. Consciente de sua posição subalterna, a protagonista se aproveita de todos as circunstâncias para conhecer os meandros da existência no engenho e acaba por cair nas graças do padremestre da sinhazinha, recebendo dele uma educação relativamente esmerada. Esse talvez seja o primeiro grande gesto de resistência da personagem, uma vez que ela fará da escrita o seu ganha-pão desde o momento em que se vê abandonada junto com a companheira de infância no Convento do Carmo em Salvador, tornando-se cartorária-fantasma do convento:

Queria ela me contratar para estar permanentemente a seu serviço, sob segredo, e estava por isso disposta a pagar-me, perguntando meu preço. Lembrando as lições de Antónia, propus uma quantia para mim bastante alta, acrescentando logo que, por ser ela quem era, eu aceitaria servi-la. Tão ansiosa estava Sor Adélia que imediatamente aceitou o trato e assim me fiz cartorária de fato do convento, como longamente Vos relatei no início desta desordenada carta. Assim me deu Nossa Senhor a graça de fazer-me capaz de prover as necessidades de minha Blandina e de nós, suas servidoras, sem sequer ter de sair à rua, embora eu o fizesse para abastecer nossa dispensa ou, vez por outra, apenas para aliviar-me do encerramento entre grossos muros (REZENDE, 2019, p. 103). 
É interessante mencionar que Blandina e Isabel são transferidas do engenho para Salvador porque aquela, depois de um romance como Diogo Lourenço, engravida e deixa de ter valor como moeda de troca para a sua família. Inconformada com o destino imposto pelo pai, a fidalga acaba por se alienar mentalmente, adoecer e morrer pouco tempo depois. Como não tinha dote nem para o casamento nem para permanecer como freira do claustro, Isabel é obrigada a sair do convento e se vê numa condição de total marginalidade. É nessa posição de fragilidade que a protagonista também acaba por se entregar a Diogo Lourenço, acreditando em suas promessas de viagem e casamento. Vendo-se enganada, Isabel fica consternada e o seu acesso de fúria devido ao golpe é interpretado como demência pelas demais pessoas:

Como louca corri, com a carta na mão, atravessei todo o convento sem nada ver, batendo-me contra móveis, colunas e gentes pelo caminho, como cega, de ódio ou de amor, não saberia dizer, saí pela porta afora e fui parar dentro daquele antro escuro a procurar por ele. Meus olhos, então, ainda ofuscados pelo forte sol das ruas, eram de fato incapazes de distinguir alguém nas sombras (REZENDE, 2019, p. 105).

Vendo-se privada da relativa proteção dada às mulheres pelo convento, mesmo quando no papel de servidoras, Isabel se disfarça de homem e passa a exercer a função de escrevente que, segundo ela mesma, era um trabalho que lhe permitia ganhos relativamente bons, dada a carência de pessoas alfabetizadas na Colônia: "Fazendo-me de macho, dotado do talento da escrita bela e escorreita, munido de folhas de papel, uma boa pena de metal, um frasco de tinta, [...], me aventurei pelas ruas e tavernas, a ganhar tostões às custas de iletrados senhores" (REZENDE, 2019, p. 114). No entanto, a protagonista tinha consciência do perigo que corria, mesmo sob disfarce, numa cidade relativamente cosmopolita como Salvador e, por isso, prefere partir ainda disfarçada para a capitania das Minas, novo epicentro econômico da Colônia:

\footnotetext{
Montando a mula que recebi em pagamento de várias ordens régias falsificadas com perfeição para um rico clérigo, juntei-me a um bando que para lá se dirigia pelos caminhos do sertão, trazendo consigo tudo o que tinham e acolá faltava, podendo-se vender com muito lucro [...]. Para isso muito lhes serviam meus préstimos já que iletrados, não podiam nem se defender das fraudes nem fraudarem eles mesmos os contratadores dos caminhos, pontes e passagens onde não se pode escapar do recolhimento ou do furto (REZENDE, 2019, p. 115).
}

Como forma de resistência, Isabel acaba por se tornar também uma espécie de auxiliar das fraudes e dissimula então a sua posição de mulher: "Sem jamais suspeitarem da minha 
condição de fêmea, segui os demais, por rios, estradas ou por veredas e picadas clandestinas" (REZENDE, 2019, p. 115). No entanto, a protagonista é traída pela própria natureza - chega sem que ela mesma perceba o seu período menstrual - é descoberta e tem todos seus pertences saqueados por soldados e companheiros de viagem:

[...] já às portas da vila de Sabará, traiu-me a natureza: ao saltar da montaria para apresentar aos oficiais da guarda minha perfeitamente falsificada certidão de batismo, viu-me um jorro de sangue manchar e escorrer pelo couro da sela e por entre as pernas de meu calção que já fora branco. Agarraram-me todos, por bem ou por mal, não sei, despiram-me das botas e do calção, não pude mais esconder quem sou e as vestes arrancadas me tomaram, meus instrumentos de trabalho e a pecúnia que eu com eles ganhara, já não me pertencia, já nada tinha a perder, senão uma vaga esperança de encontrar meu pai (REZENDE, 2019, p. 116).

Assim que é libertada por Gregório, antigo companheiro de seu pai que vivia em Sabará, Isabel volta a se disfarçar de homem e parte desta cidade para Vila Rica, centro urbano mais importante da capitania. É em Vila Rica que a protagonista, após ser atacada e ser ameaçada de estupro pelas suas maneiras delicadas demais para um homem, percebe que precisa de outras formas de resistir e sobreviver e, para isso, se vale de uma nova dissimulação: o de uma beata andarilha que viaja de cidade em cidade, vivendo da caridade das pessoas. É a partir desse ponto que Isabel se torna uma espécie de líder de outras mulheres também impossibilitadas de se casarem ou de entrarem para a vida religiosa. $\mathrm{O}$ crescimento do grupo acaba por chamar a atenção das pessoas, entre elas um proprietário de terras do Norte de Minas que lhe oferece uma porção de terra para ela e as companheiras viverem. Ao assentar morada nesse local, Isabel acaba por se tornar alvo de um processo em que Coroa e Inquisição acusam-na de tentar criar uma ordem religiosa irregular ${ }^{9}$ na Capitania das Minas e, condenada, é levada para o recolhimento em Olinda, onde escreve seu relato.

É preciso, antes de continuarmos, refletir que o relato de Isabel guarda um aspecto de dupla resistência e isso fica claro no próprio gesto de narrar a trajetória pessoal. Paul Ricoeur, no primeiro volume de Tempo e narrativa (2011), chama a atenção para um aspecto que ele considera fundamental para a apreensão do tempo: a narrativa é o único modo do homem se tomar no tempo e no espaço e, portanto, refletir-se. Nesse sentido, toda narração é uma retomada do vivido engastada numa reflexão acerca desse mesmo vivido. Se tomamos as duas primeiras partes do texto de Rezende, o que podemos notar aí é uma tentativa de afirmação de

\footnotetext{
${ }^{9}$ Segundo informações trazidas pela própria Maria Valéria Rezende, era expressamente proibida a instalação de conventos e seminários no território de Minas Gerais no século XVIII. Uma das razões para tal proibição era o receio, por parte da Coroa, de contrabando de ouro e pedras preciosas.
} 
Isabel como um sujeito da escrita e, para isso, ela se apresenta, mas não se narra, isto é, não põe em primeiro plano a sua experiência pessoal nesse momento. Na terceira parte, "1791", a protagonista, depois de se posicionar enquanto um sujeito da escrita disposto a questionar a ordem do mundo, passa a contar suas peripécias e é partir desse ponto que temos a emergência do que chamamos dupla resistência, esboçada tanto no gesto da escrita quanto no seu conteúdo.

Acerca do conteúdo, é preciso lembrar que todos os gestos de Isabel - a reação à tentativa de estupro na adolescência, a dissimulação de uma vida beata no Norte Minas, passando pelo processo de travestimento - podem ser lidos como gesto de resistência porque são nascidos da necessidade de se proteger para sobreviver em um mundo em que a marginalização da mulher é uma regra, assim como a atribuição de um valor de troca ao feminino também estavam na ordem do dia. Ao assumir os múltiplos papéis de resistência, Isabel, assume-se como sujeito feminino. Temos, então, uma personagem que, de certo modo, adianta a reflexão de Simone de Beauvoir acerca do ser-mulher: "Não nasce mulher, torna-se mulher. Nenhum destino biológico, psíquico, econômico define a forma que a fêmea humana assume na sociedade" (BEAUVOIR, 1967, p. 09).

É preciso ainda, com relação aos gestos de resistência de Isabel, levar a consideração o processo de oposição a que muitas mulheres se engajaram tanto na metrópole (e toda Europa) quanto nas colônias de modo a impedir a normatização e domesticação femininas segundo os moldes definidos pelas Igrejas cristãs, bem como pelo aparato estatal, centrado nesse contexto, na pessoa do rei absoluto que se atribuía uma governança baseada no direito divino. De acordo com essas instituições, era desejável que todas as mulheres se casassem, mas na realidade colonial, a marginalização das mulheres pobres impedia esses casamentos.

Em Calibã e a bruxa (2019), Sílvia Federici trata dessas questões a partir de um olhar para o processo de acumulação primitiva de capital. Segundo a estudiosa, ao longo do processo de implementação do capitalismo em sua faceta primária, o mercantilismo, houve um projeto de alienação da vida e da produção femininas, inserindo-as num campo de reprodução que não só desvalorizava sua produção profissional, mas também estimulava a sua não participação no projeto econômico. É a partir desse processo de inserção da mulher no campo da reprodução que ela estará fadada às funções de esposa, mãe e trabalhadora doméstica. O fato, contudo, é que boa parte dessas mulheres não se encaixavam no perfil de casadoiras e isso, de certo modo, as atiravam para marginalidade, especialmente para a prostituição.

Apesar dessa realidade, houve, ainda de acordo com Federici, vários momentos em 
que mulheres solteiras, que não desejavam nem a saída na prostituição nem a vida religiosa, formaram comunidades em que havia divisão de trabalhos e lucros e assim se protegiam das múltiplas formas de violência do mundo masculino. É claro que tanto para o Estado quanto para a Igreja não era desejável que mulheres afrontassem o sistema e vivessem numa espécie de contracultura, desse modo, tais comunidades eram atacadas e violentadas. É importante notar que a comunidade construída por Isabel em terras mineiras tem essa mesma finalidade que as comunidades de mulheres na Europa e é combatida exatamente porque oferecia às mulheres marginalizadas uma alternativa de sobrevivência e, também, de existência num mundo marcado pelo autoritarismo masculino.

$\mathrm{O}$ ato de escrever, por sua vez, emerge como um dado fundamental de resistência, especialmente se levarmos em consideração a escassez de mulheres alfabetizadas numa Colônia, onde a alfabetização de homens já era um dado circunstancial. Podemos então entender a existência de Isabel como duplamente resistente porque configurada como uma espécie de ponto fora da curva na normalidade da vida colonial. Nesse sentido, o elemento de força e, portanto, de resistência presente nas primeiras duas partes do romance (mas não só) são as rasuras que a protagonista faz de seus comentários acerca de como se organiza o poder colonial e o modo como esse poder atinge a vida de mulheres pobres ou fidalgas, pertencentes à vida secular ou à vida religiosa:

[...] Rainha sois, mas nem por isso sois menos mulher, e sofrer e chorar é o quinhão de todas as filhas de Eva, não obstante sua condição neste mundo, porque em todas as condições, aqui nestas colônias, em África, nas Índias, na China ou no Reino, no paço real ou na mais pobre aldeia do Vosso Império, estão submetidas às leis dos homens que muito mais duras são para as fêmeas e só para elas se cumprem, pois todos os seus pais e irmãos e filhos e varões quaisquer, clérigos ou seculares, só as querem para delas se servirem e para dominá-las [...]. Perdoai-me a rasura, Senhora, que se ia correndo a pena sem peias pelo papel. Corria a pena levada por inconvenientes palavras que teimam escapar do sítio onde trato de tê-las bem atadas no meu espírito (REZENDE, 2019, p. 10 grifos nossos) $)^{10}$.

O início do romance, como dissemos, vem marcado por outros exemplos de apartes críticos da protagonista que se vale da pretensa condição de enlouquecida para, ironicamente, dizer tudo o que deseja. Nesse sentido, as rasuras realizadas por Isabel são, do ponto de vista da diegese, mais uma dissimulação que revela uma personagem profundamente consciente dos meandros do poder masculino institucionalizado ou não na Colônia. Elas, longe de serem

\footnotetext{
${ }^{10}$ Em vez de usar a rasura, conseguida graficamente por um traço em cima do escrito, optamos pelo itálico para mostrar o tom de censura sarcástica utilizado pela protagonista durante a narração.
} 
rasuras reais, são, de fato, comentários sarcásticos propositais que tem a finalidade de confrontar autoridade e se vale do lugar da fragilidade - ser mulher e louca - para se proteger. Do ponto de vista da composição do romance, essas rasuras se mostram um forte procedimento estético que tem por objetivo construir um efeito de crítica irônica e bemhumorada, o que não invalida a seriedade do que é dito. Além das rasuras, o processo de composição que tem na restauração criativa de um modo de escrever inerente ao século XVIII brasileiro e nos cortes e lacunas de escrita, consequência das crises da protagonista e da carência de papel e tinta para escrever são elementos procedimentais que fazem do texto de Rezende um dos romances responsáveis pela renovação do gênero na atualidade.

Temos, desse modo, em Carta à rainha louca uma narrativa que acaba por se constituir na intersecção entre uma escrita esteticamente engenhosa, aliada a um posicionamento ético que tem na representação do feminino um elemento de força. $O$ romance, valendo-se da História, descortina opressões passadas pelas mulheres do passado e ilumina não só a continuidade das opressões, mas também o caminho das resistências.

\section{CONSIDERAÇÕES FINAIS}

Como afirmamos no início do presente texto: ao analista da literatura contemporânea é sempre um desafio reconhecer elementos de renovação na produção literária da atualidade e em suas linhas de força. No entanto, se o desafio é gigantesco, não significa que não possamos esboçar pequenas tentativas de compreensão desse grande número de produções.

$\mathrm{O}$ que nos parece bastante claro, no que diz respeito à literatura realizada nas últimas décadas no Brasil, é a escolha, por parte de alguns escritores, de uma forma de escrever que tem na ética da representação das minorias um fundamento importante. É também essencial repetirmos que essa escolha pela representação das vozes ex-cêntrica não tem como consequência um descuido com a estética, com o trabalho escritural, em suma, com um projeto literário. E nos parece que Carta à rainha louca está no rol desses projetos que aliam ética e estética a partir de um processo criativo que tem na (re)criação da forma escritural colonial, nos comentários irônicos da protagonista e na relação com a História um traço fundamental.

É preciso mencionar que o projeto de Rezende, ao compor um romance que dialoga e constrói embricamentos com a História, acaba por constituir um inventário que serve ao passado e ao presente: Isabel, criação ficcional da escritora, alegoriza, de certo modo, a trajetória das inúmeras mulheres que foram silenciadas e oprimidas pelas instituições - 
família, Estado, religião - e que são benjaminianamente redimidas. Nessa redenção, a História é redesenhada, reconfigurada e redefinida de modo, não a apagar os vencedores e consagrar vencidos, mas mostrar que as formas de resistência do passado exigem que, no presente, a desistência não seja uma opção. Esse é talvez o compromisso ético que Rezende nos entrega.

\section{REFERÊNCIAS BIBLIOGRÁFICAS}

BEAUVOIR, S. O segundo sexo: A experiência vivida (tomo II). 2.ed. Trad.: Sérgio Milliet. São Paulo: Difusão Européia do Livro, 1967.

BENJAMIN, W. O anjo da história. 2.ed. Trad.: João Barrento. Belo Horizonte: Autêntica, 2012, p. 07-20.

DIDI-HUBERMAN, G. Diante do tempo: História da arte e anacronismo das imagens. 2.reimp. Trad.: Vera Casa Nova e Márcia Árbex. Belo Horizonte: EditoraUFMG, 2019.

FEDERICI, S. Calibã e bruxa: Mulheres, corpo e acumulação primitiva. Trad.: Coletivo Syncorax. São Paulo: Elefante, 2017

HUTCHEON, L Poética do pós-modernismo. Trad. Ricardo Cruz. Rio de Janeiro: Imago, 1991.

MACIEL, N. Maria Valéria Rezende lança Carta à rainha louca. Correio braziliense, Brasília, s/p, 15/04/2019.

Disponível in: https://www.correiobraziliense.com.br/app/noticia/diversao-earte/2019/04/15/interna diversao arte,749491/maria-valeria-rezende-lanca-carta-a-rainhalouca.shtml. Acesso em: 20/12/2020.

RANCIÈRE, J. Os nomes da História: Ensaio de política do saber. Trad.: Mariana Echalar. São Paulo: Editora Unesp, 2014.

REZENDE, M. V. Carta à rainha louca. São Paulo: Alfaguara, 2019.

RICOEUR, P. Tempo e narrativa - volume 1: A intriga e a narrativa histórica. São Paulo: WMF/Martins Fontes, 2011. 